\title{
A thematic analysis of Palahniuk's fiction in light of Epicureanism
}

\author{
Hesamoddin Shahriari ${ }^{1}$, Ghazal Toosi ${ }^{2}$ \\ ${ }^{1}$ Department of English, Ferdowsi University of Mashhad, IRAN \\ ${ }^{2} \mathrm{MA}$ in English Literature, Tabriz University, IRAN \\ e-mails: ${ }^{1}$ h.shahriari@um.ac.ir; ${ }^{2}$ ghazal.toosi.literature@gmail.com
}

\begin{abstract}
Chuck Palahniuk is a contemporary American writer whose novels have been adapted into acclaimed Hollywood motion pictures. Palahniuk's literary style is often branded as modernist with nihilistic undertones. In spite of such views, in this article, we argue that through a close reading of Palahniuk and a critical interpretation of the recurrent themes in his novels, one can find traces of Epicurean philosophy echoed through the ages. Though different in means, both Palahniuk and Epicurus seem to highlight the importance of and the strive for achieving a state of ataraxia through overcoming fear and aponia through transcending physical pain and torment. After providing an introduction to Epicurean thought and Palahniuk's style and works, connections will be established between the various shared elements and themes.
\end{abstract}

Keywords: Epicurus; Chuck Palahniuk; Contemporary American Fiction; Ataraxia.

\section{INTRODUCTION}

Throughout history, numerous ideologies and philosophical perspectives have emerged; aiming to shed light upon the mysteries of human existence. Of the many schools of thought, some have proven to be more lasting, while others have been quite ephemeral and transitory, precipitating the emergence of other, more elaborate or comprehensive outlooks the echoes of which remain in the realm of human thought, as if permanently, in spite of their apparent absence from the stage of intellectual history. Reviewing the long list of by-gone ideologies, one tends to confront patterns of similitude and the resurfacing of seemingly forgotten notions. This can possibly be attributed to patterns or images of repeated human experience which Jung terms archetypes (D. \& Jung, 1979). These older, apparently dated philosophies often resurrect themselves in various forms and disguises, such as fiction, drama and other literary genres. In the present paper, we seek to argue that the ideas of ancient Greek philosopher Epicurus (341-270 BC) can be traced in the works of contemporary American author, Chuck Palahniuk. To fulfill this purpose, following an introduction to Epicureanism and Palahniuk's fiction, a detailed discussion on the similarities and differences between the works of the two figures will be presented. It is hoped that by going through the article, readers will realize that despite the great time lapse (over 20 centuries); traces of
Epicurean philosophy can be found in Palahniuk's works of fictional narrative and the mentality of his central characters.

\section{EPICUREANISM}

Epicurus lived in the fourth century. B.C, and founded an eponymous school of philosophy known as Epicureanism. What remains of him today is chiefly in the form of fragments and letters; and most of what we know about Epicureanism comes down to us from his students and followers (O'Keefe, 2014). Norman Wentworth DeWitt, in his Epicurus \& His Philosophy, states that Epicurus is the most revered and the most reviled of all founders of thought in the GrecoRoman world. His character and his doctrines became the special target of abuse for each successive school and sect (DeWitt, 1964, p.3). However, upon closer scrutiny, it could possibly be argued that his views shifted the emphasis from the political to the social virtues and offered what may be called a religion of humanity (DeWitt, 1964).

Appearing directly after Plato, Epicurus rejected and warned his disciples against the Platonic view of the universe as described in the Timaeus. He concentrated on Ethics and made pleasure the end of life (Wilson, 2013). But what Epicurus means by pleasure is not the pleasures of the moment or individual sensations, but that pleasure which endures throughout a lifetime 
(Copleston, 1993). This pleasure is to be found mostly in the serenity of the soul. By "serenity of soul," Epicurus also meant bodily health; however, his emphasis is rather on intellectual pleasure. This is because intellectual pleasure is capable of overcoming bodily pains or at least rendering them endurable. Therefore, one is advised to bear certain corporeal deprivations and hardships, especially when it is likely to prevent more severe pains or better yet, lead to intellectual gratification (Jones, 2016). Epicurus himself summarizes this emphasis in the following quote:

“...At times we pass over many pleasures when any difficulty is likely to ensue from them; and we think many pains better than pleasures when a greater pleasure follows them, if we endure the pain for a time." (Copleston, 1993, p. 407)

In Epicurean philosophy, not all pleasures are viewed the same; and not every pleasure is worthy of being indulged. What is more, not every pain is inimical. Within this frame of thought, one is encouraged to ponder the consequences of one's choices, and decide whether they bear promises of future pain or pleasure (Thrasher, 2012). In sum, according to Epicurus, pleasure is not an absolute dogma, but a relative contextual concept.

The roots of man's unhappiness, Epicurus believed, either lie in his fear or unlimited desire. He believed that the "wise man" will not multiply his needs, since that would increase his sources of pain (Copleston, 1993). Hence, by curbing one's needs and aspirations, it is possible to achieve ataraxia, a lucid state of existence characterized by freedom from worry or other such preoccupations. He even went so far as to declare that the wise man can be perfectly happy even when undergoing bodily torture (Copleston, 1993, p. 408). This spirit of endurance can be exemplified by a story about the philosopher Epictetus. Epictetus was born into slavery, and it is said that one day, his master was tightening a shackle to his leg when Epictetus cautioned that his leg was about to break. The master ignored the warnings and eventually broke the man's leg, upon which the poor slave merely said, "There, didn't I tell you it would break?" (Inwood, 2000). This story clearly illustrates how, as claimed by Epicurus, suffering rises from attempts to control what is uncontrollable.

Another highly important and much valued concept in Epicureanism is that of friendship, without which one cannot live a secure and tranquil life (Copleston, 1993). Epicurus also denied divine providence and immortality, the fear of which he believed prevents us from enjoying our real day-to-day lives. As outlined above, Epicureanism, as any other philosophical sect, has a principled philosophical frame comprising of details in various respects; however, the preceding discussion merely elaborated on the major and most basic tenets of this philosophy.

\section{PALAHNIUK AND HIS FICTION}

Chuck Palahniuk is a contemporary postmodern American novelist whose works have aroused many debates in literary circles. Because of the deviant contexts and atypical characters in his fiction, some critics have labeled him as a "shock writer" and his fiction, as Jeffrey A. Sartain calls it, transgressive (Keesey, 2016). In fact, Palahniuk has frequently been identified as a postmodern author whose works can be specifically labeled as transgressional fiction. Palahniuk is almost obsessed with pushing the boundaries of his subject matter and his style makes frequent use of repetition and colloquial, every day language. His writing style is almost voyeuristic in that it gives readers a glimpse into people's bizarre lives and their unique (and often perverted) values, beliefs and theories.

Fight Club is Palahniuk's best-known novel, which has won the Pacific Northwest Booksellers Association Award and the Oregon Book Award for Best Novel. The plot revolves around Joe, the narrator of the story, who tries to rid himself of his old life and identity through the aid of a schizophrenic alter-ego called Tyler Durden, only to discover that he and Tyler are the same person. This revelation occurs at the end of the story and by then, Joe finds himself a slave to the will of his imaginary compatriot. Another widely-reviewed novel by Palahniuk is titled Invisible Monsters. The plot of this work follows the story of Shannon, a supermodel trying to make a new story of her life by getting rid of the beauty that has placed her in captivity all through her life by shooting herself in the face.

Both novels, especially the former, have constantly fueled discussions about Palahniuk and his literary style. In fact, many critics have used Fight Club as a prototype of Palahniuk's fiction from which they have attempted to extract his writing concerns and philosophical beliefs (Ramey, 2014). The present article will also attempt to use the aforementioned works as representatives of Palahniuk's style and recurring themes.

R. F. A in his article "The capitalist Cuckoo's Nest" looks at Fight Club as a work that is limning a portrait of a standard modern individual in America. $\mathrm{He}$ elaborates on the concept of conformity and nonconformity/rebellion in society and the reflection of 
such a concept in Fight Club. R. F. A introduces Tyler Durden as the anarchist and the epitome of a character who does not conform to society. He concentrates on the last chapter of the book in which the narrator finds himself in a mental institution stating how a life of confusion brought about by social pressures can produce a mentally-unstable individual, unfit to live within the same society that made him what he is. Although he discusses the role of such psychological variables as the absence of a father figure, he again shifts his focus on the theme of rebellion against society lying at the core of the novel and the author's encouraging attitude towards it. While R. F. A holds a social outlook to this novel, Lars Bernaerts turns to more structural issues and takes its narrative texture into consideration.

Bernaerts (2009) studies the theme, structure and effects of madness in the fictional world of Fight Club through a rhetorical and narrative analysis. She investigates how this particular manifestation of madness which she calls narrative delirium is constitutive to the narrative. According to Bernaerts (2009), delirium/delusion becomes the engine of the textual dynamics in Fight Club and progresses the narrative, and is a more determining and actual factor than the supposed real world (in a context of literary postmodernism). She believes that the narrator has projected all the qualities he can only wish for, alongside the repressed inner reality in his delirious figure, Tyler Durden. Therefore, by taking into account and analyzing features of narrative delirium, Bernaerts (2009) shows how delirium plays a key role in the imaginative structure of modern texts. However, it should be noted that another important issue in the context of Fight Club is the question of masculinity and the theme of violence which has been the subject of many essays and debates.

Boon (2003) explores the relationship between men and violence in Fight Club and the effects that transformations in American culture during the second half of the twentieth century have had on men. He elaborates on how Palahniuk's fight club addresses the identity crisis of white, heterosexual, American men in the late $20^{\text {th }}$ and early $21^{\text {th }}$ centuries. During this period, transformations in American culture led to a paradoxical cultural environment that made heroes of aggressive men while debasing aggressive impulses. According to Boon (2003), dealing with such contradictions between what is explicitly asked of these men (cultural rhetoric) and what is implicitly expected (cultural expectations) results in the eventual loss of power, and leads to men seeking to preserve and re-establish their masculinity/ manhood. Boon (2003) believes that Fight Club is populated with such men who have turned to violence as a means of achieving resurrection and forming their masculine identities. He discusses how the rigid standards of traditional masculine behaviors, specifically violence in this context, are ironically liberating.

In "One-Dimensional Men: Fight Club and the Poetics of the Body", an article on the film adaptation of Fight Club by acclaimed director David Fincher, Groønstad (2003) states that Fight Cub is a synopsis of a century-long discourse in American arts and letters on the meaning and substance of violence and masculinity. In this article, there can be found signs of philosophical outlook when Groønstad (2003) claims that the Durden persona formulates an ethical philosophy that in some respects is indebted to Levinas' postulation that suffering implies "the impossibility of nothingness" because pain means to be "directly exposed to being" (p. 4). However, after this brief reference, the article reverts to the position of treating the concepts as manifesting the marginalization of Masculinity in a hyper-modern society, the feminization of culture, and related themes revolving around similar central motifs as discussed in the preceding articles reviewed thus far.

Bunn (2008) also joins these critics in tracing signs of masculinity in Palahniuk's narratives in his article. He then claims that by assembling such bizarre and obscure facts, Palahniuk's fiction manages to reach out and appeal to young straight men. It seems that Palahniuk himself testifies to such a claim by declaring in his interview with Bunn that "It's a guy thing" (p. 53). Bunn also states that a bright nihilism pervades in Palahniuk's risky, propulsive novels. This claim has been made by many other critics in literary circles who have accused Palahniuk of holding nihilistic views. However, the author himself claims he is not a nihilist, but a romantic, and that his works are merely mistaken for being nihilistic because they express ideas that others do not believe in (Keesey, 2016).

Finally, Palahniuk's works have even been interpreted through a modern, scientific perspective. Sartain (2005), for instance, has adopted a scientific standpoint, and has attempted to study Palahniuk in light of modern scientific theories. He examines how the language of contemporary science, astounding discoveries in non-linear dynamics (chaos theory), particle physics, or information theory have permeated and infused Palahniuk's fiction.

Considering the aforementioned works and the debates they have generated, it seems that as pointed out by Groønstad (2003), a discussion of Palahniuk can scarcely avoid the subject of modernity and more 
importantly, the question of masculinity in $20^{\text {th }}$ century American culture. Such a perspective, though quite relevant and useful in understanding Palahniuk, seems to have grown repetitive, stale and lost its vitality of subject and, to borrow Derrida's term, its "aphoristic energy" of writing (Johnson, 1999). Considering this, a fresh perspective through which one can attain a more focused, and hopefully, more accurate view of Palahniuk's fictional world seems necessary. To achieve this goal, we have taken a long step back from modernity into the past and examined how Palahniuk's overarching themes and philosophical outlook (detached from the modern-day American context) can possibly be traced back to that of Greek philosopher Epicurus, writing as early as the 4th century B.C.

\section{DISCUSSION}

One particular point of similarity between the philosophy of Epicurus and the ideals held by Palahniuk's characters is the characterization of happiness and how it can be attained. Epicurus believed that a man's unhappiness takes root either from fear or unlimited and vain desires and was a proponent of simple inexpensive habits. Similarly, in most of his works, Palahniuk creates characters that are unhappy due to the shackles of material existence which have bound them from transcendence. Palahniuk's characters inhabit a world in which:

"You tell yourself, this is the last sofa I will ever need in my life, buy the sofa, then for a couple years you're satisfied that no matter what goes wrong at least you've got your sofa issue handled. Then the right set of dishes. Then the perfect bed. The drapes. The rug. Then you're trapped in your lovely nest, and the things you used to own; now they own you" (Palahniuk, 1996, p. 29).

It is not until the characters free themselves from their material attachments that they feel true happiness. This is exemplified through an episode of Fight Club in which the narrator blows his condominium out through his schizophrenic alter-ego, Tyler Durden, to set himself free of the possessions that have now come to possess him.

"I'm breaking my attachment to physical power and possessions,' Tyler whispered, 'because only through destroying myself can I discover the greater power of my spirit."' (Palahniuk, 1996, p. 77)

This outlook to existence is paralleled in Epicureanism, according to which virtues such as simplicity, moderation, temperance, and cheerfulness, are much more conducive to pleasure and happiness than are "unbridled luxuries, a feverish ambition" and so on (Copleston, 1993, p. 409). Epicurus states that the happiest among men are those who have arrived to "the point of having nothing to fear from those who surround them" (Copleston, 1993, p. 409). Palahniuk also emphasizes the confronting of fear and the release from unnecessary restraint once fear has been overcome. This is clearly evident in the following excerpts:

Most guys are at fight club because of something they're too scared to fight. After a few fights, you're afraid a lot less. (Palahniuk, 1996, p. 38)

Tyler had nothing to lose. (Palahniuk, 1996, p. 79)

Me with nothing left to lose. (Palahniuk, 1999, p. 69)

The characters, who in many cases serve as the narrators of Palahniuk's novels, long to unshackle themselves and reach a state of ataraxia, a term by Epicurus meaning the quiet of mind and soul (Warren, 2006). Though Epicurus made pleasure the end of life, he emphasized intellectual pleasure since the Epicureans considered mental suffering to be far worse than bodily suffering, on the grounds that the body suffers only from present evil whereas the soul can suffer also from the recollection of past evils and the expectation or fear of future evil. Moreover, in his discussion of the wise man, he goes so far as to claim that if the wise man is being burned, if he is being tortured, he will say: 'How delightful this is! How little I care for it' (Copleston, 1993, p. 408). The manifestation of such a worldview is also portrayed in Fight Cub:

"His honor shot the wingtip into Tyler's kidneys after Tyler curled into a ball, but Tyler was still laughing. 'Get it out,' Tyler said.' Trust me. You'll feel a lot better. You'll feel great'" (Palahniuk, 1996, p. 81)

In Palahniuk's fiction, characters undergo bodily torture. Perhaps the most famous quote from the novel Fight Club is one in which Tyler asks his companion to do him a favor, and to hit him as hard as he can. The reader may wonder whether this request stems from Tyler's masochistic tendencies, but closer analysis reveals that there is apparently more to this inclination for torture and suffering than meets the eye. To understand the underlying significance of such acts, one should apply a proper spectacle to draw out meaning from the metaphorical world of Palahniuk's literary fiction. Although Palahniuk strives to represent his world as similar to our real, day-to-day lives, one should not miss the hidden metaphorical layers of meaning and hence arrive at the false conclusion that Palahniuk is actually proposing the formation of an underground club, formed by a group of men in which they merely 
gather to fight one other in turn. Pondering this fictional world through its own metaphoric medium, one soon comes to realize that the characters in Fight Club are searching for the essence of their existence. They fight to reach ataraxia at the expense of bodily torture. The fighting is actually not only external and physical, but also internal and spiritual. It is an inner struggle with one's own self and vain ambitions. In a sense, it is an internal form of dialogism, the outcome being peace and a more intimate understanding of oneself. The following quotes will help explain this idea.

After fight club, you're so relaxed, you just cannot care. (Palahniuk, 1996, p. 101)

Tyler explained it all, about not wanting to die without any scars, and wanting to know more about him-self(Palahniuk, 1996, p. 36)

In Invisible Monsters, another novel by Palahniuk, we can also hear a similar voice, that of Shannon, the narrator of the story who is a supermodel trying to get rid of 'her old story' by doing away with her beauty. To this end, she shoots herself in the face to relieve herself, to deliver herself of the beauty which has put fetters on her freedom of mind and soul. Shannon describes her intentions from this deliberate act of self mutilation in the line below:

I was tired of staying a lower life form just because of my looks. Trading on them. Cheating. Never getting anything real accomplished, but getting the attention and recognition anyway. Trapped in a beauty ghetto is how I felt. Stereotyped. Robbed of my motivation. (Palahniuk, 1999, p. 108)

Just as the protagonist in Fight Club achieved peace through detaching himself from his worldly possessions, Shannon obtains the exact same feeling of ataraxia by disfiguring her face and ridding herself from the corporeal beauty which is viewed by most to be a blessing. After her transfiguration, Shannon expresses her achievement in the excerpt below:

Here was my life about to start all over again. I could be a great brain surgeon this time around. Or I could be an artist. Nobody would care how I'd look. People would just see my art, what I made instead of just how I looked, and people would love me. (Palahniuk, 1999, p. 108)

Epicurus denied divine providence and immortality, on the basis that he believed they cause fear, which in turn prevents us from obtaining pleasure in life. In order to account for the origin of the world, Epicurus put forward the idea of the collision of atoms bringing about the universe (Copleston, 1993). Similarly, in Palahniuk, the concept of divine providence and immortality seems to differ greatly from the usual accepted Judeo-Christian notion of God held by most American writers. In fact, in line with the Epicurean outlook, Palahniuk's characters seem to believe that this life is the only one. This stance can be clearly seen in the following quotes:

He told me that your folks are like God because you want them to approve of your life, still you only call them when you're in crisis and need something (Palahniuk, 1999, p. 44)

The mechanic says, If you're Christian and living in America, your father is your model for God. And if you never know your father, if your father bails out or dies or is never at home, what do you believe about God?' (Palahniuk, 1996, p. 103)

A third and final point of similitude to be discussed in this paper is the idea of friendship, central to both Epicurus and Palahniuk. Epicurus laid great emphasis on friendship since he believed that of all the things which wisdom provides for the happiness of one's whole life, by far the most important is the acquisition of friendship (Copleston, 1946, p. 410). In Palahniuk's fiction, characters likewise try to plant the seeds of friendship in their life to experience intimacy and closeness to other beings. One can clearly trace this concept lying at the heart of the entire institution of fight club or the support groups which Joe participates in towards the beginning of the story.

This theme surfaces in almost every work by Palahniuk; for instance, in Invisible Monsters, the characters are in search of a family, a friendly core on which they can rely. In other words, they want to care and be cared for. Palahniuk himself has been quoted to admit to this core theme in his books. In the introduction to Stranger than Fiction, a non-fiction book accounting the lives and experiences of various individuals, he writes "All my books are about a lonely person looking for some way to connect with other people." The following excerpts also bear witness to the centrality of friendship in Palahniuk's fictional universe:

Walking home after a support group I felt more alive than I'd ever felt. I was the little warm center that the life of the world crowded around. (Palahniuk, 1996, p. 12)

But hysteria is impossible without an audience. Panicking by yourself is the same as laughing alone in an empty room. You feel really silly. (Palahniuk, 1999, p. 20)

However, there appears to exist a delicate difference between the approaches taken by the two figures. While friendship in Epicurean philosophy is founded 
upon egoistic considerations, namely that without friendship a man cannot live a secure and tranquil life; friendship in Palahniuk's view, as one might understand from his works, starts from an egoistic level, and consequently moves toward a more sublimated state. In Invisible Monsters, the narrator of the story, Shannon, accompanies Brandy since she needs her.

I'm with Brandy right now, because I can't imagine getting away with this without Brandy's help. Because, right now I need her. (Palahniuk, 1999, p. 75)

However, this egoistic outlook later on takes on a more altruistic meaning. This transformation can be seen when towards the end of the novel, Shannon admits that she needs to prove to herself that she is capable of love:

I'm giving you my life to prove to myself I can, I really can love somebody. Even when I'm not getting paid, I can give love and happiness and charm. You see, I can handle the baby food and the not talking and being homeless and invisible, but I have to know that I can love somebody. Completely and totally, permanently and without hope of reward. (Palahniuk, 1999, p. 111)

Despite the similarities mentioned up to this point, one can by no means claim that Epicureanism and Palahniuk's fiction are identical in their approach. Though they may be similar in many respects, they have points of difference that distinguishes them from one another. In this section, an outline of the main points of departure between the two will be presented and briefly discussed.

Epicurean hedonism would not result in libertinism and excess, but in a calm and tranquil life (Copleston, 1946). Epicurean ethics lead to a moderate asceticism and self-control. From an Epicurean perspective, it is more pleasant to live in a society where law reigns and rights are respected (Copleston, 1946). Epicurus was against insolence and vulgarity and insisted on courtesy and decorum. This inclination resulted in his criticism of society, and his advice on being sympathetic and urbane.

In contrast, in Palahniuk, characters strive to "hit the bottom" (Palahniuk, 1996, p. 46). They want to give up the idea they have any control. While following Epicurus, one might be inclined to preserve and maintain his/her comfort to gain pleasure, Palahniuk's characters "explode" their comfort zones to gain pleasure (Palahniuk, 1999, p. 108). One might understand that in Epicureanism, people are after decorum and normality in order to live a pleasurable and tranquil life. But, the characters created by Palahniuk feel "so miserable being a normal average child" (Palahniuk, 1999, p. 107). They "want something to save them, the opposite of a miracle" (Palahniuk, 1999, p. 107). They create contrasts to what they have already experienced, to what they are accustomed to, the habits that have enslaved them. Since "There is no real sense of life" when you have "nothing to contrast it with." (Palahniuk, 1996, p. 24). The quote below helps to further explain this point.

"At the time, my life just seemed too complete, and maybe we have to break everything to make something better out of ourselves." (Palahniuk, 1996, p. 36)

Perhaps the key difference between Palahniuk and Epicurus stems from their respective historical contexts and times. Epicurus was born in 341 B.C., barely seven years since the death of Plato and only seven years prior to Alexander's conquest of Persia (DeWitt, 1964). During the youth of Epicurus, Greece was deluged by the new wealth of information concerning geography, the flora and fauna, and the divergent wisdoms of Persia and India (DeWitt, 1964, p. 10). In such a cultural context, the political social tranquility could be a proper ground for intellectual, artistic, and scientific growth.

On the other hand, Palahniuk lives in an age overwhelmed with amazing scientific breakthroughs. This mechanistic and highly industrialized world has dominated the very man who used to be its master. Palahniuk, in his fiction, portrays such a developed scientific environment in which everything seems possible to the extent that even one can determine and choose his/her gender (as seen in Invisible Monsters). According to Palahniuk, in such a hyper-real status quo, it seems that everything has turned into " $a$ copy of a copy of a copy" (Palahniuk, 1996, p. 67).

Within such an extreme context, achieving moderation, or the much sought-after state of equilibrium obligates individuals to take a step far into the opposite direction. It is only as a result of such extremities of action that, to borrow Hegelian terms, synthesis and a movement towards perfection can be gained. Palahniuk lives in a modern historical context which according to some theoreticians has already passed and according to others, is still halfway on its path towards postmodernism, and the much prophesied "death of philosophy" (Connor, 2004).

Postmodern philosophy has turned western orthodoxies and value systems on their head. Richard Rorty, a postmodern thinker, believes "edification" is supposed to be abnormal, to take us out of our old selves through the power of strangeness, to aid us in 
becoming new beings (Connor, 2004, p. 24). Palahniuk's characters are also after "a new story" telling them who they are. While in Epicurus' era, the society was in search of development and completeness, in Palahniuk's era; as portrayed in his fiction, individuals' lives just seem "too complete" (Palahniuk, 1996, p. 129).

"...And maybe we have to break everything to make something better out of ourselves." (Palahniuk, 1996, p. 36)

\section{CONCLUSION}

Chuck Palahniuk, as one of the most well-known contemporary postmodern writers on the stage of American literature, has aroused many debates in literary circles and among critics. However, most of these discussions have aimed to interpret Palahniuk's new transgressional postmodern fiction in light of modernism or modernist theories. Such an approach, though quite helpful, seems to have lost its novelty and has overshadowed new outlooks towards Palahniuk. With this in mind, a reconsideration of Palahniuk's fiction that could potentially lead to a fresh view and interpretation of his works seems to be essential. Taking a far step back to ancient philosophy, one may understand that the philosophical views, put forward by Palahniuk through the medium of his novels, bear similitude to those presented by Epicurus, the ancient Greek philosopher.

Though similar in many key features, the philosophical notions of these two figures also have their distinct points of difference. However, these differences can be characterized as different paths ultimately leading to the same destination, as opposed to a divergent point in a philosophical route. These differences may be attributed to the different historical settings in which these two thinkers have emerged, urging them to take on different means in order to achieve a unified end. Epicurus, as an influential ancient Greek philosopher, and Palahniuk, as an important modern American writer, give voice to similar ideas that entice people to be aware of the value and essence of their being and existence, so that they can improve the quality of their life, make it pleasurable and thus make the most out of their existence.

\section{REFERENCES}

Bernaerts, L. (2009). Fight club and the embedding of delirium in narrative. Style, 3(43), 373-88.

Boon, K. A. (2003). Men and nostalgia for violence: culture and culpability in Chuck Palahniuk's fight club. The Journal of Men's Studies. 3(11), 267-276.

Bunn, A. (2008). Open book: Chuck Palahniuk writes stories that fearlessly expose the darkest parts of the human experience. So why is it that when it comes to his sexuality there are still some things he likes to keep hidden? The Advocate, 18, 42-64.

Conner, S. (2004). The Cambridge companion to postmodernism. Cambridge, UK: Cambridge University Press.

Copleston, F. (1993). A history of philosophy volume I. New York, NY: Doubleday.

D., C. \& Jung, C. (1979). C. G. Jung collected works. The American Journal of Psychology, 92(4), 754.

DeWitt, N. W. (1964). Epicurus \& his philosophy. Minneapolis, MN: University of Minnesota Press.

Groønstad, A. (2003). One-dimensional men: Fight club and the poetics of body. Film Criticism, 1(28), 1-8.

Inwood, B. (2000). Epictetus: Discourses book I. Philosophical Review, 109(4), 639-642.

Johnson, C. (1999). Derrida (1st ed.). New York: Routledge.

Jones, H. (2016). Epicurean tradition (1st ed.). [Place of publication not identified]: Routledge.

Keesey, D. (2016). Understanding Chuck Palahniuk. South Carolina: The University of South Carolina Press.

O'Keefe, T. (2014). Epicureanism (1st ed.). Hoboken, NJ: Taylor and Francis.

Palahniuk, C. (1996). Fight club. New York, NY: Henry Holt \& Co.

Palahniuk, C. (1999). Invisible monsters. London, UK: W. W. Norton \& Company.

Ramey, M. (2014). Studying fight club ( $1^{\text {st }}$ ed.). Leighton Buzzard, England: Auteur.

R. F. A. (2002). The Capitalist cuckoo's nest. Human Architecture, 1(1), 1-8.

Sartain, J. (2005) Even Mona Lisa's falling apart: The cultural assimilation of scientific epistemologies in Palahniuk's fiction. Stirrings Still, 2(2), 25-47.

Thrasher, J. (2012). Reconciling justice and pleasure in epicurean contractarianism. Ethical Theory And Moral Practice, 16(2), 423-436.

Warren, J. (2006). Epicurus and democritean ethics (1st ed.). Cambridge, UK: Cambridge University Press.

Wilson, C. (2013). Epicureanism at the origins of modernity (1st ed.). Oxford, UK: Clarendon Press. 